Yanna Ivanova, post-graduate student, Department of General and Differential Psychology, South Ukrainian National Pedagogical University named after K. D. Ushynsky, 4, Fontanska Doroha Str., Odesa, Ukraine

\title{
PASSIONARITY AND EXISTENCE: INTERRELATION OF EMPIRICAL PARAMETERS
}

The article deals with the results of the carried out empirical research aimed at identifying the interrelation of passionarity components and meaningfulness of life. In the historical context, passionarity is considered as a process that sets vectors of the development of the society and an individual. Passionarity manifestation can be understood as a constructive confrontation of a personality with existential anxiety. It is also considered as individual susceptibility to the transformation of the reality (changing environment) aimed at implementing sustainable functional goals in the space of personal existence affirmation. Passionarity is connected with the existential needs of an individual. The correlation analysis has been carried out in order to identify the interrelation of passionarity components and meaningfulness of life. It has shown that some indicators of passionarity and meaningfulness of life are interrelated, which indicates a certain proximity and interdependence of these properties. The review of the essence of the revealed interrelations means that passionarity activates the protective adaptive mechanism in the experience of existential anxiety and frustration and helps an individual to find integrity. The actualisation of the search behaviour contributes to finding new solutions to avoid behavioural stereotypes. The search behaviour supports the desire for expression of personality, authenticity. The discovered positive relations of the indices of passionarity and meaningfulness of life, which reflect different aspects of existence, indicate the interdependence of these phenomena. It has been found that the emotional component of passionarity creates some difficulties in getting existential fullness. Passionarity is associated with self-distancing, self-transcendence, freedom, meaningfulness of life. The high energy potential of passionarity, readiness to overcome barriers on the way of achieving a goal, focus on the future, search and implementation of the existentially meaningful tasks, allow an individual to live a meaningful life.

Keywords: passionarity, existence, meaningful life, sustainability of goals, transformation of reality.

Подано до редакиії 30.03.2016

УДК: 159.922 .6

Інна Василівна Кирильчук,

асистент кафедри соиіальної та практичної психології, Житомирський державний університет імені Івана Франка, вул. Велика Бердичівська, 40, м. Житомир, Україна

\section{ОСОБЛИВОСТІ ФОРМУВАННЯ СУБ 'ЄКТНОСТІ УЧНЯ В ПІДЛІТКОВОМУ ВІЦІ}

У статті розглядаються особливості формування суб'єктності учня в молодшому підлітковому віці. Представлено результати дослідження складових суб'єктності молодшого підлітка, щзо визначають успішність соиіалізації його на етапі переходу в середню школу. Обтрунтовано, щчо формування суб'єктності учня в підліковому віиі - безперервний динамічний процес, який відображає рівень активності підлітка, його відповідальності, вибірковості, ставлення до себе, учбової діяльності. Стосунки з учителем та однокласниками спонукають молодшого підлітка до саморозвитку, до усвідомлення своєї самоцінності і иінності іншої людини.

Ключові слова: здібності, суб'єктність, навчальний процес, иүінності, підлітковий вік.

У підлітковому віці провідною залишається навчальна діяльність, яка характеризується вибірковою готовністю, підвищеною сприйнятливістю до навчання. Значним досягненням учня середніх класів $€$ його готовність до усіх видів навчальної діяльності, які допомагають сприймати себе «дорослим» у власних очах. Потреба у самоствердженні стає актуальною потребою цього віку. На даному етапі особистісного розвитку підліток намагається реалізувати дану потребу у сфері соціальних відносин та навчальній сфері.
Процес соціалізації проявляється у включенні підлітка в нову систему стосунків, в опануванні нових соціальних функцій, в ціннісному ставленні до власних здібностей як основного способу задоволення своїх потреб. Навчальна діяльність стає тією сферою, яка зумовлює становлення школяра як суб'єкта цієї діяльності. Саме підлітковий вік є сензитивним періодом для формування суб'єктності [2]. Важливо, щоб учень усвідомив свою суб'єктність, тобто був здатен визначати цілі власної діяльності, добирати необхідні 
для цього засоби, організовувати діяльність, відрефлексовувати й оцінювати результати.

Проблема становлення особистості школяра як суб'єкта навчальної діяльності привертала увагу багатьох вчених (К.О. Абульханова-Славська, Л.І. Анциферова, Г.О. Балл, М.Й. Бори-шевський, А.В. Брушлинський, С. Д. Максименко, С.Л. Рубінштейн, В.О. Татенко та ін.). У працях цих авторів суб'єктність розглядається як невід'ємна характеристика суб'єкта, що проявляється в усвідомленні себе як частини світу. Людина виступає в світі суб'єктом, який володіє певними властивостями, можливостями, здатністю до активності і саморозвитку. В суб'єктності розкриваються найважливіші характеристики людини, що забезпечують задоволення іiі потреб у самореалізації та самоздійсненні.

Суб'єктність розглядається як центральне утворення людської реальності, що виникає на певному рівні розвитку особистості та інтегрує такі їі характеристики, як активність, рефлексивність, ініціативність, творчість, самодетермінація, саморегуляція, усвідомленість, самостійність та ін. [1]. Суб'єктність виступає як спосіб життя, властивість, яка формується в процесі життєдіяльності та розкривається, переважно, у ставленні людини до явищ, речей, оточуючих та до самого себе і знаходить свій прояв у конкретних діях, коли вони для людини починають виступати у якості засобів. На думку В.О. Татенка, дане психічне утворення розвивається протягом усього життя, проявляється в різних сферах на різних рівнях взаємодії 3 оточенням: «Суб'єктність притаманна кожній людині, хоча може бути вираженою різною мірою» [8, с.240].

Особистість може характеризуватися як суб'єкт тією мірою, в якій вона використовує свій інтелект, свої здібності, підпорядковує свої нижчі потреби вищим, будує своє життя відповідно зі своїми цінностями і принципами. А.В. Брушлинський, досліджуючи феномен суб'єкта, писав, що людина як суб'єкт є найвищою системною цілісністю всіх їі найскладніших і суперечливих якостей, і сама людина, будучи від початку свого існування активною, стає суб'єктом у процесі спілкування, діяльності та інших видів активності [2]. Вчений пише, що 3 дорослішанням «...все більш вагоме місце посідають саморозвиток, самовиховання, самоформування і, відповідно, більшу питому вагу мають внутрішні умови, через які завжди діють зовнішні причини, впливи і т.д.» [2, с. 4.].

Волкова О.М., досліджуючи структуру суб'єктності молодших підлітків, виокремлює чотири атрибутивні іiі компоненти: активність, свідомий характер діяльності, самосвідомість і відповідальність як наслідок свободи [3]. На різних стадіях становлення ці компоненти мають різний психологічний зміст, обумовлений характером навчальної діяльності та рівнем особистісного розвитку.

Дані про суб’єктність як інтегративну якість особистості школяра, що об'єднує такі характеристики як активність, самостійність, рефлексивність, конструк- тивну взаємодію з навколишнім середовищем, прагнення до саморозвитку ми зустрічаємо в працях О.А. Конопкіна, Г.А. Цукерман [5, 9].

Про форму вираження суб'єктності в параметрах «особистісна безпорадність» та «самостійність» говорить І.Я. Зязюн. Він зазначає, що, в залежності від того, в якій точці даного континіуму, в верхній - «самостійність» чи нижній - «безпорадність», буде знаходитися людина, можна говорити про пї рівень суб'єктності. Даний підхід дає можливість визначити здатність дитини перетворювати оточуючу дійсність, свідомо керувати власною діяльністю (у нашому випадку - навчальною).

Уміння учня самостійно приймати важливі рішення, нести за них відповідальність, контролювати їх дотримання та виконання, обстоювати для самого себе та оточуючих правильність і доцільність цих рішень впливають на подальший розвиток його когнітивної, емоційної та вольової сфери.

Таким чином, важливою передумовою виникнення і підтримання суб'єкт-суб'єктної взаємодії у навчальному процесі є створення умов для формування і розвитку суб' єктності учнів у навчальній діяльності як форми актуалізації їх творчої активності.

Метою статті є 3'ясування сутнісного розуміння суб'єктності в контексті саморозвитку особистості підлітка; презентування результатів емпіричного дослідження компонентів суб'єктності учнів 5-6 класів

Дослідження проводилося на базі Житомирської загальноосвітньої школи I-III ступенів №6 серед учнів 5-6-их класів. Загальна вибірка становила 56 осіб. Компоненти суб'єктності базуються на основі структури критеріальної моделі суб'єктності О.М. Волкової та I.A. Серьогіної [3]. Емпіричними дескрипторами суб'єктності визначено такі: життєстійкість (адаптивність), особистісна спрямованість, емоційно-вольове ставлення до навчання, самоставлення та суб'єктна активність.

Вибір конкретних психодіагностичних методик визначався необхідністю дослідження психологічних особливостей та механізмів, що обумовлюють динаміку суб'єктності у процесі навчальної діяльності молодших підлітків.

Для вивчення особливостей особистісної спрямованості школяра був використаний модифікований варіант опитувальника В. Смойкла, М. Кучера «Оцінка особистісної спрямованості».

Діагностика особливостей суб'єктної активності кожного учня здійснювалася за допомогою анкети експертної оцінки, яка була розроблена за допомогою вчителів-предметників.

Для діагностики емоційно-вольових компонентів ставлення до навчальної діяльності школярів була застосована проективна методика «Незакінчені речення», яка дозволяє визначати рівень прояву вольових, емоційних та інтелектуальних складових суб'єктності. 
Діагностика адаптаційних можливостей особистості як складової суб'єктності учнів середньої ланки здійснювалася за багаторівневим особистісним опитувальником «Адаптивність» А. Маклакова та С. Чермяніна (модифіковний варіант). Даний опитувальник дає змогу оцінити соціально-психологічні та деякі психофізіологічні характеристики учня, що відображають узагальнені особливості соціального розвитку і включає такі шкали: «Нервово-психічна стійкість» (НПС); «Комунікативні здібності» (КЗ); «Моральна нормативність» $(\mathrm{MH})$ та «Особистісний адаптивний потенціал» (ОАП).

Для визначення змісту самосвідомості молодших підлітків була використана методика діагностики адекватності самооцінки «Я-реальне, Я-ідеальне» (за Будассі)

Представимо результати констатуючого дослідження, спрямованого на визначення особливостей динаміки розвитку суб'єктності молодшого підлітка в звичайних умовах навчання.

Дослідження емоційно-вольового ставлення до навчання включало вісім категорій: ставлення до процесу навчання, до школи, до однокласників, до ролі учня, до вибору навчальних завдань, до уроків, до вчителів та до себе. Отримані результати в ході емпіричного дослідження за методикою «Незакінчені речення» свідчать про те, що в учнів з високим рівнем успішності 5 та 6 класу переважають позитивні думки щодо навчального процесу, вчителів, ролі учня та вибору навчальних завдань. Для даної вибірки важливозначимим залишається спілкування 3 вчителями («Мені легко спілкуватися 3 вчителем, який справедливий та який сприймає учня як повноцінну людину»). Відмінникам властиве вміння контролювати ситуацію власної успішності та спілкування з вчителями; відповідально ставитися до досягнення цілей у виконавській діяльності. У досліджуваних визначається важливою потреба в області досягнень в навчальній діяльності, що спонукає їх до пізнавальної активності. Так підлітки вважають, що усього доброго в своєму житті, вони здатні досягнути самостійно, завдяки власним зусиллям («Важкі завдання я вибираю частіше, щоб краще вчитися та бути успішним», «Важкі завдання дають можливість мені мислити краще»). В даної вибірки досліджуваних в більшій мірі розвинені здібності до рефлексії та до свободи вибору способів вирішення складних завдань, а також спостерігається нижча оцінка у прийнятті іншої людини. Для школярів із нижчим рівнем успішності характерним $є$ краще ставлення до однокласників, друзів та до ролі учня.

Ціннісне ставлення до навчання включає в себе характеристики, які передбачають розвиток у дітей різної спрямованості особистості. У п'ятикласників домінує особистісна спрямованість, яка створює перевагу мотивів власного успіху, прагнення до особистої першості. У школяра $з$ такою спрямованістю про- являється зацікавленість більше власними потребами та переживаннями, ніж потребами оточуючих. У навчанні він бачить, насамперед, можливість задовольнити свої домагання. Спрямованість на взаємодію спостерігається в більшій мірі у шестикласників, коли вчинки та дії школярів визначаються їхньою потребою в спілкуванні, прагненням підтримувати гарні відносини $з$ ровесниками. Їх цікавить не стільки кінцевий результат діяльності, скільки сама спільна діяльність.

Порівняльний аналіз адаптаційних можливостей досліджуваних школярів показав, що найбільш значимі відмінності проявляються у шестикласників 3 вищим рівнем успішності. А саме, такі учні мають достатній рівень працездатності, у тому числі, і в ускладнених умовах діяльності. Вони достатньо швидко адаптуються у новому колективі. При встановленні міжособистісних контактів 3 оточуючими, як правило, не зазнають труднощів. На критику реагують адекватно. У цілому орієнтовані на дотримання загальноприйнятих і соціально схвалених норм поведінки.

Порівняльний аналіз показників розбіжностей між Я-реальним та Я-ідеальним учнів з високим рівнем успішності обох вибірок показав статистично достовірні відмінності в бік зростання середніх значень за такими показниками, як інформаційний пошук $(\mathrm{p}<0,01)$, особливості самоконтролю та самооцінки $(\mathrm{p}<0,01)$, організаторські здібності $(\mathrm{p}<0,01)$, наполегливість в області досягнень $(\mathrm{p}<0,01)$. Для учнів 3 низьким рівнем успішності характерними виявилися наступні показники: відповідальність $(\mathrm{p}<0,01)$, емоційна сфера $(\mathrm{p}<0,01)$ та організаторські здібності $(\mathrm{p}<0,01)$.

У ході констатуючого дослідження встановлено, що середні значення показників суб'єктності, залишаючись практично стабільними для п'ятикласників та шестикласників, достовірно зменшується в учнів середнього та низького рівня успішності обох вибірок.

Здійснений кореляційний аналіз структур суб'єктності учнів 5 та 6 класів дозволив нам встановити, що ступінь взаємозв'язку компонентів у структурі суб'єктності підвищується у пятикласників і різко знижується в шестикласників.

Формування суб'єктності учня в підліковому віці - безперервний динамічний процес, який відображає рівень активності підлітка, його відповідальності, вибірковості, ставлення до себе, учбової діяльності. Відносини з учителем і однокласниками спонукають молодшого підлітка до саморозвитку, до усвідомлення своєї самоцінності і цінності іншої людини.

Перспективу подальших досліджень вбачаємо у розробці програм розвитку суб'єктності учнів молодшого підліткового віку, що дозволить покращити суб'єкт-суб'єктну взаємодію у навчальному процесі для актуалізації творчої активності школяра. 


\section{ЛІТЕРАТУРА}

1. Абульханова-Славская К. А. Акмеологическое понимание субъекта / К. А. АбульхановаСлавская // Основы общей и прикладной акмеологии.: M., 1995. - 388 c.

2. Брушлинский А. В. Проблема субъекта в психологической науке / А. В. Брушлинский // Психол. журн. - 1991. - Т. 12. - № 6. - С. 3-11.

3. Волкова Е. Н. Исследование структуры субъектности в младшем подростковом возрасте с разным уровнем игровой компьютерной зависимости / Е. Н. Волкова, А. В. Гришина // Психологическая наука и образование. - 2015. - Т.20. - №1 - С. 328-342.

4. Зязюн I. А. Свобода діяльності суб'єктів учіння у цілепокладанні громадянської активності / I. А. Зязюн // Науковий вісник Міжнародного гуманітарного університету. Історія. Філософія.Політологія. - 2010. - Вип. 1. - С. 47-53

5. Конопкин О. А. Феномен субъектности в

\section{REFERENCES}

1. Abulkhanova-Slavskaya, K. A. (1995). Akmeologicheskoie ponimanie subiekta [The akmeological understanding of the subject]. Osnovy obschei $i$ prikladnoi akmeologii - Bases of general and applied acmeology. Moscow [in Russian].

2. Brushlinskiy, A. V. (1991). Problema subiekta v psihologicheskoy nauke [The problem of the subject in psychology]. Psihol. Zhurnal-Psychological journal, 12, 3-11, [in Russian].

3. Volkova, E. N., Grishina, A. V. (2015). Issledovaniie struktury subiektnosti $\mathrm{v}$ mladshem podrostkovom vozraste s raznym urovnem igrovoi kompiuternoi zavisimosti [The study of subjectivity structure in early adolescence with different levels of addiction to computer gaming]. Psikhologicheskaia nauka i obrazovanie - psychological science and ув Т.20, 1, p. 328-342, [in Russian].

4. Zyaziun, I. A. (2010). Svobpoda diialnosti subiektiv uchinnia u tsilepokladanni gromadyanskoyi aktivnosti [The freedom of activity of learning targets in civic engagement]. Naukovyi visnyk Mizhnarodnoho humanitarnoho universitetu. - Scientific bulletin of International humanitarial university 1, 47-53 [in Ukrainian].

5. Konopkin, O. A. (1994). Fenomen subiektnosti v psihologii lichnosti [The phenomenon of subjectivity in психологии личности / О. А. Конопкин // Вопросы психологии. - 1994. - № 6. - С. 148-150.

6. Музика О. Л. Суб'єктно-ціннісний аналіз особистісного росту / О. Л. Музика // Науковий часопис НПУ імені М.П.Драгоманова. Серія №12. Психологічні науки: 3б. наукових праць. - К.: НПУ імені М.П.Драгоманова. - 2005. - № 6 (30). - Ч.І. - С. 137-143.

7. Осницкий А. К. Проблемы исследования субъектной активности / А. К. Осницкий // Вопросы психологии. - 1996. - № 1. - С. 5-19.

8. Татенко В. А. Субъект психической активности : поиск новой парадигмы / В. А. Татенко // Психологический журнал. - 1995. - Т. 16. - № 3. - С. 23-35.

9. Цукерман Г. А. От умения сотрудничать к умению учить себя / Г. А. Цукерман // Психологическая наука и образование. 1996. - № 2. - С. 27-42.

psychologyof personality]. Voprosy psikhologii - Issues of Psychology, 6, 148-150 [in Russian].

6. Muzyka, O. L. (2005). Subiektno-tsinnisnii analiz osobistisnogo rostu [The subject-value analysis of personal growth]. Naukovyi chasopys NPU Imeni M.P.Dragomanova - Scientific bulletin of M. P. Dragomanov national pedagogical university, 6 (30), 137-143. Kyiv: NPU Imeni M.P. Dragomanova [in Ukrainian].

7. Osnitskii, A. K. (1996). Problemy issledovaniya subiektnoi aktivnosti [Issues of studying the subject actvity]. Voprosy psikhologii - Issues of psychology, 1, 519 [in Russian].

8. Tatenko, V. A. (1995). Subiekt psikhicheskoi aktivnosti : poisk novoi paradigmy [The subject of mental activity: the search for a new paradigm]. Psikhologicheskii zhurnal - Psychological journal, 3, 23-35 [in Russian].

9. Tsukerman, G. A. (1996). Ot umeniia sotrudnichat $\mathrm{k}$ umeniiu uchit sebia [From the ability to cooperate to the ability to self-teaching]. Psikhologicheskaia nauka $i$ obrazovaniie - Psychological science and education, 2, 27-42 [in Russian].

\section{Инна Васильевна Кирильчук, ассистент кафедры социальной и практической психологии, Житомирский государственный университет имени Ивана Франко, ул. Большая Бердичевская, 40, г. Житомир, Украина}

ОСОБЕННОСТИ ФОРМИРОВАНИЯ СУБЬЕКТНОСТИ УЧЕНИКА В ПОДРОСТКОВОМ ВОЗРАСТЕ

В статье рассматриваются основные научные подходы к изучению проблемы формирования субъектности учащихся подросткового возраста. В психологической науке разработаны такие структурные компоненты субъектности, как активность, самостоятельность, рефлексивность, стремление ко взаимодействию с окружающей средой, к саморазвитию, эмоциональное отношение к учебной деятельности, отражение учащимися собственных способностей и т.д. Исследование эмоционально-волевого отношения к учебе включало восемь категорий: отношение к процессу обучения, школе, одноклассникам, роли ученика, выбору учебных задач, урокам, учите- 
лям и к себе. Полученные в ходе эмпирического исследования результаты по методике «Незаконченные предложения» свидетельствуют о том, что у учащихся 5 и 6 классов с высоким уровнем успеваемости преобладают позитивные мысли относительно учебного процесса, учителей, роли ученика и выбора учебных задач. Для данной выборки важным остается общение с учителями. Отличникам свойственно умение контролировать ситуацию собственной успешности и общения с учителями; ответственно относиться к достижению целей в исполнительской деятельности. У исследуемых проявляется потребность в достижениях в учебной деятельности,что побуждает их к познавательной активности. Так, подростки считают, что всего хорошего в своей жизни они способны достичь самостоятельно, благодаря собственным усилиям. В данной выборке испытуемых в большей степени развиты способности к рефлексии и к свободе выбора способов решения сложных задач. Для школьников с низким уровнем успешности характерно более позитивное отношение к одноклассникам, друзьям и к своей роли ученика. Ценностное отношение к учебе включает в себя характеристики, которые предусматривают развитие у детей различной направленности личности. У пятиклассников доминирует личностная направленность, которая создает преобладание мотивов собственного успеха, стремление к превосходству. У школьника с такой направленностью проявляется заинтересованность больше собственными потребностями и переживаниями, чем потребностями окружающих. В учебе он видит, прежде всего, возможность удовлетворить свои притязания. Направленность на взаимодействие наблюдается в большей степени у шестиклассников, когда поступки и действия школьников определяются их потребностями в общении, стремлением поддерживать хорошие отношения со сверстниками. Их интересует не столько конечный результат деятельности, сколько сама совместная деятельность. Сравнительный анализ адаптационных возможностей исследуемых школьников показал, что наиболее значимые различия проявляются у шестиклассников с высоким уровнем успеваемости. В частности, такие ученики имеют достаточный уровень работоспособности, в том числе, и в осложненных условиях деятельности.

Ключевые слова: способности, субьектность, учебный процесс, ценности, подростковый возраст.

Inna Kyrylchuk, assistant of the Department of Social and Applied Psychology, Zhytomyr State University named after Ivan Franko, 40, Velyka Berdychivska Str., Zhytomyr, Ukraine

\section{PECULIARITIES OF FORMING SCHOOL STUDENT'S SUBJECTIVITY IN ADOLESCENCE}

The article deals with the basic scientific approaches to the study of the issue of the formation of students' subjectivity in the educational process. Most researchers understand subjectivity as the highest form of regulation of behaviour, active manifestation of abilities in making significant changes in oneself and the surrounding reality. The carried out empirical research involved $565-6^{\text {th }}$ graders. The study of emotional and volitional attitude towards the educational process involved 8 categories: attitude towards studying, school, classmates, student's role, choice of tasks, attitude towards lessons, teachers and oneself. The results obtained by means of the method "Incomplete sentences" have shown that the respondents with the high level of academic performance have positive thoughts about the educational process, tasks and teachers. Communication with teachers is considered to be very important for them. The students with the high level of intelligence are self-confident; they are sure that they can achieve goals without any help. These adolescents have highly developed reflection skills. The respondents with the low level of academic performance are characterised by the positive attitude towards classmates and their role of school students. They can be also described by the personal focus, which makes the motives of personal success predominant. Due to this such school students are interested in their own needs and feelings more than in other people's problems. They consider the educational process as an opportunity to satisfy their ambitions. Focus on the collaboration has been found in the sample of $6^{\text {th }}$-graders. Their deeds and actions are determined by their need for communication, the desire to have good relations with classmates. They are interested not in the final result of their studying, but in the process of joint activities. The comparative analysis of the adaptation capacity of the respondents has shown that the most significant differences are manifested among $6^{\text {th }}$-graders with the high academic performance level.

Keywords: abilities, subjectivity, educational process, values, adolescence. 